УДК 37.7

DOI:

Олександра Кирилова, аспірант кафедри теоретичних дисциплін та професійної освіти Київської державної академії декоративно-прикладного мистеитва і дизайну імені Михайла Бойчука

\title{
ПОНЯТТЯ “АРТ-ПЕДАГОГІКА” У КОНТЕКСТІ НАУКОВО-ТЕРМІНОЛОГІЧНОГО АПАРАТУ ПРОФЕСІЙНОЇ ПЕДАГОГІКИ
}

У публікаиії розглядається визначення та зміст арт-педагогіки уконтексті науково-термінологічного апарату професійної педагогіки, як складової мистечької освіти. Визначено арт-педагогіку як систему супроводу прочесу професійної підготовки майбутніх дизайнерів, результатом якої є створення культурномистецького продуктув процесі професійного навчання, щуо залучає студентів до проектної, науково-творчоі діяльності та сприяє формуванню сталих професійних знань, дизайнерських умінь і навичок, забезпечує розвиток психічних, фізіологічних процесів та особистісних рис майбутніх дизайнерів. Доведено, щчо арт-педагогіка являє собою комплексне, міждисциплінарне поняття, щэо зумовлює його тлумачення в різних галузях наукових знань. Виокремлено аспекти арт-педагогіки: педагогічний, психологічний, фізіологічний, культурологічний, мистецтвознавчий та подано їх характеристику.

Ключові слова: арт-педагогіка; підготовка фахівиів з дизайну; мистеиька освіта; науково-творча діяльність; дизайнерські уміння і навички.

Jim. 5.

Oleksandra Kyrylova, Postgraduate Student of the Theoretical Disciplines and Vocational Education Department Kyiv Mykhaylo Boychuk State Academy of Decorative Arts and Design

\section{THE NOTION “ART PEDAGOGY” IN THE CONTEXT OF THE SCIENCE-BASED TERMINOLOGICAL APPARATUS OF PROFESSIONAL PEDAGOGY}

The publication deals with the definition and content of art-pedagogy in the context of the scientificterminology apparatus of professional pedagogy as a component of artistic education. Art pedagogy is defined as a system of support for the process of professional training of future designers, the result of which is the creation of a cultural and artistic product in the process of professional training, which attracts students to the design, scientific and creative activities and promotes the formation of sustainable professional knowledge, design skills and development, provides development psychological, physiological processes and personality traits of future designers. It is proved that art-pedagogy is a complex, interdisciplinary concept that determines its interpretation in various branches of scientific knowledge. The aspects of art-pedagogy are singled out: pedagogical, psychological, physiological, cultural, art studies and their characteristics are presented. The article reveals the necessity for the application of art-pedagogy in professional design education in the process of project activity on the basis of interdisciplinary ligaments and represent as the synthesis of arts and the combination of educational disciplines: drawing, painting, sculpture, study of art history, architecture, design, calligraphy, photography, music and dance. At the same time, presentations of their own creative, artistic projects, video tapes direct to the art house, visits to virtual museums and international, domestic exhibitions and design salons are important. Innovative technology, the application of art-pedagogy in the professional activities of future designers requires a special study.

Keywords: an art-pedagogy; training the specialists in design; artistic education; the scientific and creative activities; the design skills and development; interdisciplinary ligaments; synthesis of arts; the combination of educational disciplines.

П остановка проблеми. У новій редакції "Закону про вищу освіту” акцентовано увагу, що “мистецька діяльність є невід'ємною складовою освітньої діяльності закладів вищої освіти, культурологічного та мистецького спрямування і провадиться з метою поглиблення професійних компетентностей, інноваційної діяльності в мистецтві, що сприяє створенню нового культурно-мистецького продукту" [1].

3 огляду на окреслене вище, актуальною проблемою в організації дизайн-освіти закладів вищої мистецької освіти є застосування артпедагогіки, оскільки вона сприяе формуванню професійної компетентності майбутнього дизайнера різних спеціалізацій: дизайн середовища (ландшафту та інтер'єру), графічний дизайн (webдизайн), промисловий дизайн та створенню інноваційного мистецького продукту.

Аналіз основних досліджень та публікацій. У працях В. Анісімова, А. Байєре, О. Булатової, В. Гришиної, А. Козир, Л. Лебедєвої, 


\section{ПОНЯТТЯ “АРТ-ПЕДАГОГІКА” У КОНТЕКСТІ НАУКОВО-ТЕРМІНОЛОГЧЧНОГО АПАРАТУ ПРОФЕСІЙНОЇПЕДАГОГІКИ}

Д. Мерфі, Н. Миропольської, О. Сороки, О. Хаустової викладено педагогічні засади арт-терапії, зокрема йдеться про форми оранізації та інклюзивну освіту. У науковому доробку зарубіжних науковців розглянуто проблему арт-терапії (О. ДьюхерстМеддок, С. Дженнінгс, К. Роджерс та ін.). Теоретичні, методичні та методологічні засади арт-педагогіки викладено у наукових працях Р. Верховодової, Л. Волкової, Т. Добровольської, А. Козир, В. Кокоренко, Л. Комісарової, І. Левченко, Н. Миськової, Н. Сергеєвої, Т. Руденької тощо.

Незважаючи на наявність численних наукових досліджень 3 проблем висвітлення окремих питань арт-педагогіки, слід зазначити, що здебільшого ці наукові розвідки не висвітлюють підготовку майбутніх дизайнерів, а

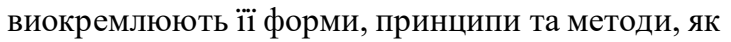
корекційні соціально-педагогічними технології, техніки та тренінги. Нами не виявлено самостійних наукових досліджень комплексного характеру у контексті порушеної нами проблеми.

Мета та завдання статті: визначити зміст, сутність та аспекти арт-педагогіки у контексті науково-термінологічного апарату професійної педагогіки, як складової мистецької освіти.

Виклад основного матеріалу. Насамперед вважаємо за доцільне конкретизувати поняття “арт-педагогіки" $з$ метою уточнення його сугності, змісту, оскільки здебільшого ця дефініція розглядається та ототожнюється з арт-терапією, упсихолого-педагогічній літературі висвітлюється у “вузькому” розумінні цього поняття як розвиток творчих здібностей, креативності, потенціалу. Так, нами виокремлено праці в яких арт-педагогіка розглядається як соціально-педагогічна діяльності 3 дітьми і особами з особливими потребами; в системі технологій професійної підготовки фахівців (О. Булатова, Ж. Валєєва, М. Гузєва, М. Катренко, Л. Лєбєдєва, В. Соколова).

Звернімо нашу увагу на те, що арт-педагогіка, яка за твердження дослідниці О. Рудницької виникла на основі арт-терапії, “спрямована на розв’язання соціально-педагогічних, психотерапевтичних іпсихокорекційних завдань” $[4,65]$.

Цінним для нашого дослідження є визначення “арт-педагогіки”, запрпоноване Т. Руденькою. Розглядаючи формування професійної компетентності майбутніх фахівців мистецьких спеціальностей у закладах професійно-технічної освіти засобами арт-педагогіки, науковець визначає арт - педагогіку як практикоорієнтований напрям педагогічної науки, предметом дослідження якої $\epsilon$ природа, закономірності, принципи, форми і методи залучення мистецтва i художньо-творчої діяльності для вирішення завдань професійної підготовки фахівців [3, 7].

Водночас Т. Руденькою схарактеризовано основні методи арт-педагогіки: роз'яснення, аналіз творів мистецтва, тематичний відбір художніх творів, метод контрадикторних переконань, аналіз проблемних ситуацій, художнє відтворення мистецької ідеї. Розкрито їх аксіологічний потенціал у професійній підготовці фахівців [3, 8].

На наше переконання, застосування артпедагогіки у професійній дизайн-освіті має відбуватися у процесі проектної діяльності на основі міжпредметних зав'язків та являти собою синтез мистецтв та поєднання навчальних дисциплін: рисунок, живопис, скульптура, вивчення історії мистецтва, архітектури, дизайну, каліграфії, фотографії, музики, танцю. Разом $з$ тим, важливе значення мають презентації власних творчих, мистецьких проектів, перегляд відеострічок напряму арт-хаус, відвідування віртуальних музеїв та міжнародних, вітчизняних виставок та салонів-дизайну.

Водночас теоретико-методологічний, технологічний інструментарій мистецтва, що грунтується, перш за все, на специфіці видів мистецтва (музико-терапія; образотворче мистецтво - образо-терапія; театр, образ - імаго-терапія; література, книга - бібліотерапія; танець, рух - кінезітерпаія), педагогіки, психології, соціології, філософії, естетики і забезпечує інтеграцію гуманітарних знань 3 метою поліпшення професійної підготовки майбутніх дизайнерів різних спеціалізацій. Інноваційна технологія, застосування артпедагогіки у професійній діяльності майбутніх дизайнерів вимагає спеціального дослідження.

У ході дослідження ми дійшли висновку, що аналізовані нами літературні джерела не містять усталеного, загальноприйнятого визначення дефініції “арт-педагогіка” у професійній дизайносвіти. 3 огляду на це, метою нашої публікації $є$ конкретизація визначення цієї терміносполуки. Результати наукового пошуку свідчать, що дефініцію “арт-педагогіка” слід розглядати на основі міждисциплінарного підходу, оскільки вона грунтується на досягненнях багатьох галузей знань:

- педагогіки;

- психології;

- фізіологіі;

- культурологіï;

- мистецтвознавства.

Розглянемо окреслені аспекти більш детальніше.

Педагогічний аспект передбачає єдність таких заходів: 


\section{ПОНЯТТЯ “АРТ-ПЕДАГОГІКА”У КОНТЕКСТІ НАУКОВО-ТЕРМІНОЛОГЧНОГО АПАРАТУПРОФЕСІЙНОӤПЕДАГОГІКИ}

- розробку комплексу навчально-методичних та навчальних програм (“Синтез художнього проектування та образотворчого мистецтва”, “Комплекс інноваційних технологій застосування арт-педагогіки упрофесійній підготовці майбутніх дизайнерів”, “Методичні рекомендації застосування арт-педагогіки для підготовки майбутніх дизайнерів” тощо;

- розробка документації з урахуванням та дотриманням дидактичних принципів і вимог професійної педагогіки;

- добір спеціальних форм, методів, організації мистецької діяльності (пленери, етюди, замальовки, копіювання у музеях, відвідування сучасних виробництв із метою поглибленого вивчення досягнень промислового дизайну тощо; важливо застосувати інноваційний метод поєднання класичних вправ з рисунку, живопису, композиції із проектно-творчими ідеями студентів. Такий підхід дає можливість розвивати творчу уяву студентів, використовуючи фундамент художньої майстерності, зокрема, грамотне володіння закономірностями зображення форм, пропорцій і композицій);

- забезпечення міжпредметних зв'язків між фаховими і теоретичними дисциплінами (живопис iз історією мистецтва; web-дизайн із каліграфією; вивчення комп'ютерних програм із основами кольорознавства та композицією і архітектонічною творчістю (архітектура, декоративно-прикладне мистецтво, дизайн).

Психологічний аспект. Арт-педагогіка сприяє забезпеченню тривалості навчально-творчої діяльності. Так, йдеться про такі психологічні умови:

- соціальні умови (згуртованість колективу, зниження рівню напруженості і конфліктності, підвищення рівня комунікаційних навичок тощо);

- психолог-фізіологічні умови (врахування індивідуально-психологічних особливостей студентів, забезпечення психологічного комфорту в колективі, формування особистісних моральних якостей);

- психокорекційні (уникнення стресів, психологічних травм, застосування арттерапевтичних вправ, технік, технологій, застосування різноманітних художніх матеріалів 3 метою забезпечення психологічного здоров'я);

- фізіологічні умови (розвиток розумової працездатності, дрібної моторики, впровадження здоров'язберігаючих технологій тощо).

Культурологічний аспект передбачає вивчення і усвідомлення матеріальних і духовних цінностей, спосіб буття і організації повсякденного життя, етносів, націй на різних історичних етапах
3 метою компіляції здобутків світової культури в створенні сучасного культурно-мистецького продукту в інтер'єрі, ландшафтномудизайні, webдизайні, костюмі тощо.

Р. Павлюк вбачає обумовленість культурологічної функції в об'єктивному зв'язку особистості 3 культурою та їі цінностями, у розвитку особистості дизайнера шляхом оволодіння художньою культурою та проектною творчістю [2].

Таким чином, культурологічний аспект освітньої функції арт-педагогіки скеровує розвиток особистості засобами мистецтва, спонукає iї засвоювати дійсність, забезпечувати взаємодоповення з дисциплінами естетики інших наукових галузей. Так, у новітній технології STEAM освіти [5] взаємопідсилюється S природничі науки, Т - технології, Е - інжиніринг, А - арт, М - математика. Тобто арт є важливим компонентом змісту навчальних дисциплін з різних галузей науки.

Мистецтвознавчий аспект передбачає вивчення закономірностей функціонування мистецтва, єдність історії і теорії мистецтва. Йдеться про: міжпредмтні зв'язки між фаховими і теоретичними дисциплінами (живопис із історією мистецтва, архітектурою; web-дизайн iз каліграфією; вивчення комп'ютерних програм із основами кольорознавства та композицією тощо); професійну підготовку майбутніх дизайнерів на основі вивчення українських народних традицій, 3 урахуванням регіональних, етнічних особливостей та культурних художніх традицій.

Висновки та перспективи подальшого розвитку. Отже, арт-педагогіка у професійній дизайн-освіті - це складова мистецької освіти. Це система арт-педагогічного супроводу процесу професійної підготовки майбутніх дизайнерів, результатом якої $є$ створення культурномистецького продукту у процесі професійного навчання. Застосування арт-педагогіки у професійній підготовці майбутніх дизайнерів сприятиме залученню студентів до пошуковотворчої, проектної діяльності на засадах синтезу мистецтв, сприяння формуванню сталих професійних знань, дизайнерських умінь і навичок; забезпечує розвиток психічних, фізіологічних процесів, особистісних рис майбутнього дизайнера. Арт-педагогіка у професійній підготовці майбутніх дизайнерів $\epsilon$ міждисциплінарним, комплексним поняттям, що зумовлює нагальність його тлумачення у контексті різних галузей знань: педагогіки (загальної, мистецької, професійної), психології (вікової, творчості), фізіології, культурології, мистецтвознавства. 


\section{ПОНЯТТЯ “АРТ-ПЕДАГОГІКА” У КОНТЕКСТІ НАУКОВО-ТЕРМІНОЛОГІЧНОГО АПАРАТУ ПРОФЕСІЙНӦ̈ПЕДАГОГІКИ}

\section{ЛІТЕРАТУРА}

1. Закон України "Про вищу освіту" [Електронний ресурс]. - Режим доступу: http:// zakon.rada.gov.ua/laws/show/1556-18

2. Павлюк Р. О. Артпедагогіка як наука: зміст, суть, значення та форми впровадження // Педагогічний альманах: зб. наук. пр. / [редкол. В.В. Кульменко (голова) та ін.]. - (17), 2013. C. $67-73$.

3. Руденька Т. М. Арт-педагогіка як інновація сучасної професійно-педагогічної теорії і практики / Т. М. Руденька // Наукові записки Ніжинського державного університетуім. Миколи Гоголя. Сер.: Психолого-педагогічні науки. - 2012. - № 4. C. 59-63. - Режим доступу: http://nbuv.gov.ua/ UJRN/Nzspp 2012414

4. Мистецька освіта в Україні: теорія i практика / О. П. Рудницька [та ін.]; заг. ред. О. В. Михайличенко, редактор Г. Ю. Ніколаї. Суми: СумДПУ ім. А. С. Макаренка, 2010. - 255 с.

5. Тименко В. П. Методика діагностики практичного інтелекту учнівської молоді [Текст]: методичнийпосібник/В.П.Тименко,А.В.Малиношевська, М. Ю. Мельник, О. Г. Грицан. - Київ: Інститут обдарованої дитини. НАПН України.- 2017. - 156 с.

\section{REFERENCES}

1. Zakon Ukrainy "Pro vyshchu osvitu" [The Law of Ukraine on higher education]. Access mode: http:/ zakon.rada.gov.ua/laws/show/1556-18 [in Ukrainian].

2. Pavliuk, R. O. (2013). Artpedahohika yak nauka: zmist, sut, znachennia ta formy vprovadzhennia [Art pedagogy as a science: content, essence, meaning and form of implementation]. Pedagogical Almanac: collection of scientific works. The editorial board: V.V. Kulmenko (head) and others (17). pp. 67-73. [Electronic resource]. Access mode: http://elibrary.kubg.edu.ua/943/1/ Roman_Pavlyuk_PA 17 FLMD_PI.pdf [in Ukrainian].

3. Rudenka, T. M. (2012). Art-pedahohika yak innovatsiia suchasnoi profesiino-pedahohichnoi teorii i praktyky [Art-pedagogy as an innovation of modern professional-pedagogical theory and practice]. Scientific notes: Nizhyn State University named after. Nikolai Gogol. Series: Psychologicalpedagogical sciences, no. 4, pp. 59-63. [Electronic resource]. Access mode: http://nbuv.gov.ua/UJRN/ Nzspp_2012_4_14 [in Ukrainian].

4. Rudnytska, O. P. (2010). Mysteczka osvita v Ukrayini: teoriya i praktyka [Artistic education is in Ukraine: theory and practice]. The editorial board: O. V. Myxajlychenko, editor: G. Yu. Nikolayi. Sumy: Sumskiy state pedagogical university of the name of A. S. Makarenko, 255 p. [in Ukrainian].

5. Tymenko, V. P., Malynoshevska, A. V., Melnyk, M. Yu. \& Grytsan, O. G. (2017). Metodyka diagnostyky praktychnogo intelektu uchnivskoyi molodi [Method of diagnostics of practical intellect of student's young people]. Methodical manual. Kyiv. Institute of gifted child NAPN Ukraine, 156 p. [in Ukrainian].

Стаття надійшла до редакції 19.10.2018

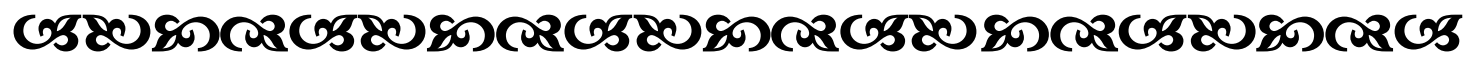

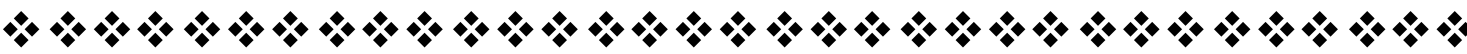

"Якщо бажаєте досягти в житті успіху, зробіть наполегливість своїм кращим другом, досвід - мудрим радником, обережність - стариим братом, а надію - ангеломхоронителем".

Dжозеб Еддісон англійський письменник-есеїст, драматург, публіиист та політичний діяч

"Рівність - це єдина і міщна основа для суспільного устрою, для порядку, зақонності, добрих звичаїв $i$ відбору на висоқі посади людей, які справді для них придатні".

Бернард Шоу

ірландський драматург і публіиист

"Насолоджуйся можливістю постійного зростання".

Невідомий автор

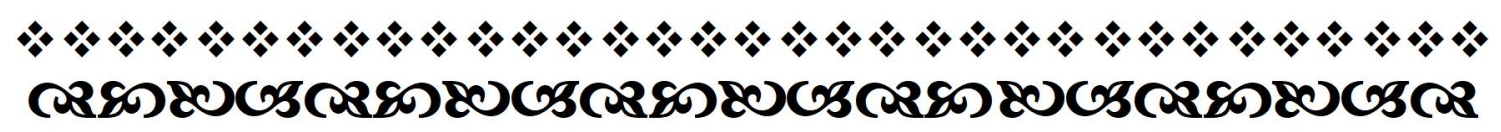

